\title{
Child Labour in the Supply Chain
}

\author{
Abstract \\ Purpose - Highlights the risks faced by companies through the use of child \\ labour in their outsourced global supply chains. \\ Design/method/approach - Explores recent research and commentary \\ on child labour in global supply chains.
}

Findings - Reveals the risk of brand damage to large organisations as a result of child labour inputs in their supply chains.

Practical implications - Guides HR practitioners in advising management on strategic and tactical approaches in sanitising supply chains of child labour.

Social implications - Draws attention to the risks associated with the presence of child labour in the supply chain and need for large companies to practice social responsibility beyond their borders.

Originality/value - Demonstrates how child labour is not just an ethical issue but a legal one as well and how injustices suffered by children can through public awareness campaigns destroy brand value of the ultimate benefactor companies.

Keywords: child labour, global supply chain, stakeholder theory, slavery, reputation capital.

Article type: General review

Exploitation of child labour is a growing area of concern in global supply chains. This year, the focus of the 'World Day Against Child Labour' (12 June 2016) was on child labour and the supply chains. Guy Ryder, International Labour Organization (ILO) Director-General proclaimed that child labour has no place in well-functioning and well regulated markets, or in any supply chain. The term "child labour" is often defined as work that deprives children of their childhood, their potential and their dignity, and that is harmful to physical and mental development. Extreme forms of child labour involves children being enslaved, separated from their families, exposed to serious hazards and illnesses and/or left to fend for themselves in large cities. According to the ILO, an estimated 170 million children are engaged in child labour, or $11 \%$ of the global population of children. Many of these child labourers work for the global supply chain. A recent report produced by the US Department of Labor gives insights into the extent of child labour exploitation and slavery covering industries such as agriculture, mining, manufacturing, and pornography around the world (US Dept. of 
Labor, Online, 2016). Perhaps the best example is the fashion supply chain that produces textiles and garments to satisfy the demand of consumers in Europe, the US, and beyond (The Guardian, Online, 2016a).The source countries for child labour for the fashion supply chain are India, Vietnam, Argentina, Bangladesh, Brazil, Cambodia, China, Nepal, North Korea, Philippines, Thailand, Ethiopia (US Dept. of Labor, Online, 2016).

The chocolate industry has struggled to stamp out widespread child labour in farms across West Africa (The Guardian, Online, 2016b). In India, child labour is employed to extract Mica, the mineral that adds a shimmer to beauty products such as blusher, eye shadow, lipstick, and foundation, as well as to the paints used by the car and construction industries. Some of the world's biggest cosmetics companies including L'Oréal and Estée Lauder, as well as suppliers such as Merck are the benefactors of the mica trade (The Guardian, Online, 2016c). In the automotive industry Vauxhall, Volkswagen, Audi, and BMW source mica for their paints from the same supply chain (The Guardian, Online, 2016d). Child labour inputs in the global supply chain could be embarrassing and potentially damage renown brands of large multi-national enterprises. In fact child labour is a reality in globalised commodities supply chain.

In the realm of stakeholder theory, employees are regarded as a key direct stakeholder in an organisation. Yet when labour inputs are externalised through third party sourcing arrangements there is no recognition of third party workers (including children) as stakeholders even as indirect stakeholders. Thereby, their welfare does come under the corporate radar. The plight of the child workers is made public predominantly by NonGovernmental Organisations (NGOs). Why should companies be proactive and audit the supply chains to safe guard their brands? Most would say that it is to safe guard the interests of the primary stakeholder, i.e. the shareholders. The use of child labour ultimately does reduce costs for companies. This is where the ethical debate begins but it really is less about the ethical in this instance than the illegality of the use of child labour as most countries have laws to protect the rights of the child.

\section{Implications for Employers/HR Practitioners}

For big brand companies, two issues arise: the illegality of child labour and brand damage (when publicised) arising from use of child labour. Some companies turn a blind eye for the sake of above average returns while others have reacted (usually due to brand damage) by carrying out audits to sanitise the supply chain of child labour. Often there is a lot of talk of social responsibility and business sustainability at management level and that is translated into policies which are more for show rather than action. The HR departments can go beyond just formulating policies to putting in place proactive processes that detect and prevent child labour inputs into the supply chain. HR can craft the processes, test the processes and then hand over the implementation to the relevant business units. In this way, 
$\mathrm{HR}$ value adds through its strategic (policy formulation), tactical (process implementation) initiatives and ensuring compliance after implementation. HR department therefore also contributes to protecting the brand image or the reputation capital of the organisation.

\section{Note}

Dr John Chelliah is Professor in Management, College of Business, Hospitality and Tourism Studies, Fiji National University, Fiji.

Contact details are: Tel: +679 3394000; E-mail:jchelliah123@gmail.com

\section{References}

International Labour Organization (2016), "End child labour in supply chains - It's everyone's business!"_http://www.ilo.org/ipec/Campaignandadvocacy/ wdacl/2016/langen/index.htm, accessed: 22 November 2016

The Guardian (2016a), "Child labour in the fashion supply chain." https://labs.theguardian.com/unicef-child-labour/, accessed: 23 November 2016

The Guardian (2016b), "Child labour is part of most of what we buy today: what can we do?" https://www.theguardian.com/sustainablebusiness/2016/nov/24/child-labour-what-can-we-do-africa-modern-slavery, accessed: 23 November 2016.

The Guardian (2016c), "Beauty companies and the struggle to source child labour-free mica." https://www.theguardian.com/sustainablebusiness/2016/jul/28/cosmetics-companies-mica-child-labour-beautyindustry-india-, accessed: 23 November 2016

The Guardian (2016d), "Vauxhall and BMW among car firms linked to child labour over glittery mica paint." https://www.theguardian.com/globaldevelopment/2016/jul/28/vauxhall-bmw-car-firms-linked-child-labourmica, accessed: 23 November 2016

United States Department of Labor (2016), "List of goods produced by child labor or forced labor." https://www.dol.gov/sites/default/files/documents /ilab/reports/child-labor/findings/TVPRA_Report2016.pdf, accessed: 22 November 2016 